\title{
Impact of anthropogenic pollution on the population of the Baikal amphipod Gmelinoides fasciatus (Stebbing, 1899) (Amphipoda: Gammaroidea: Micruropodidae) in the basin of the River Moskva and Moscow City
}

\author{
Виияние антропогенного загрязнения на попумяџию \\ байкамьского бокопмава Gmelinoides fasciatus (Stebbing, 1899) \\ (Amphipoda: Gammaroidea: Micruropodidae) \\ в бассейне р. Москва и г. Москва
}

\author{
Ivan N. Marin ${ }^{1}$, Sergey Yu. Sinelnikov ${ }^{1,2}$ \\ Иван Н. Марин ${ }^{1}$, Сергей Ю. Синельников ${ }^{1,2}$
}

\footnotetext{
${ }^{1}$ A.N. Severtzov Institute of Ecology and Evolution of RAS, Leninsky pr. 33, 117071, Moscow, Russia. E-mail: coralliodecapoda@mail.ru (corresponding author)

2 I.D.Papanin Institute for biology of inland waters of RAS, 152742, Borok, Nekouzsky region, Yaroslavl oblast, Russia. E-mail: sinelnikoff@yandex.ru

${ }^{1}$ Институт проблем экологии и эволюции им. А.Н. Северцова РАН, Ленинский просп., 33, 117071, Москва, Россия.

${ }^{2}$ Институт биологии внутренних вод им. И.Д. Папанина РАН, 152742, п. Борок, Некоузский р-н, Ярославская обл., Россия.
}

KEY WORDS: invasion, first record, amphipods, anthropogenic pollution, indicator species, Volga Basin. Волги.

КЛЮЧЕВЫЕ СЛОВА: вселение, первая находка, амфиподы, антропогенное загрязнение, бассейн

ABSTRACT. Diversity of crustacean communities of the River Moskva was investigated. Invasive amphipod Gmelinoides fasciatus (Stebbing, 1899) was found to be the most abundant and widespread macrocrustacean species. Its abundance strongly decreased in the most polluted section of the river flowing through the City of Moscow. We propose thus to consider this species as a biological indicator of anthropogenic pollution in other areas of its invasion.

РЕЗЮМЕ. Исследовано разнообразие сообществ ракообразных бассейна р. Москвы. Наиболее массовым видом является бокоплав-вселенец Gmelinoides fasciatus (Stebbing, 1899), численность которого при этом сильно снижалась в районе загрязненного участка реки, протекающего через г. Москву. Предложено использование данного вида в качестве индикатора антропогенного загрязнения в других районах его вселения.

\section{Introduction}

Gmelinoides fasciatus (Stebbing, 1899) is a native amphipod species to the coastal zone of the Lake Baikal and several adjacent lakes and rivers [Pirozhnikov, 1937; Bazikalova, 1945; Kozhov, 1947; Greze, 1957; Kamaltynov, 2001]. It is known as a coastal eurybiotic species with a wide range of adaptations to various environmental conditions: it occurs in waterbodies with different trophic status from oligotrophic (Baikal) to shallow eutrophic ones (overgrown floodplain lakes). In its native range, outside Lake Baikal, the species is also known in the area from the mouth of the Angara River to the lower stream of Yenissei [Gurjanova, 1929, 1951], where G. fasciatus has been recorded on sandy and silty-sandy substrates with frequency $23-33 \%$ [Pirozhnikov, 1937]. This crustacean species is distributed over long distances along the rivers flowing into Baikal: Selenga, Barguzin, Upper Angara etc., it inhabits many riparian and floodplain waters within the basin of rivers and some lakes of the coastal strip of the Lake Baikal. In this lake the species was recorded from the upper littoral, including the surf zone to $100 \mathrm{~m}$ depth (although there is a single report for this depth). It inhabits various (i.e. rocky, sandy and muddy) substrates, and macrophytes. During spawning G. fasciatus may form aggregations of 10000-20000 ind. $/ \mathrm{m}^{2}$ [Beckman, 1962]. The species is considered as algae feeder and scavenger. The most complete accounts of distribution and ecology of $G$. fasciatus were published by M. Yu. Beckman [1962], O.I. Mitskevich [1976, 1978, 1980, 1987] and D.V. Matafonov [2003, $2005]$.

In the Soviet time G. fasciatus was considered a good candidate species for planned introduction aimed at improvement of food resources for commercial fishes [Bekman, Bazikalova, 1951; Pirozhnikov, 1955; 
Beckman, 1962; Ioffe, Nilova, 1975]. Firstly, G. fasciatus was introduced in the Gorkovskoe reservoir (Volga Basin) in 1962-1965, while already in 1975 this amphipod successfully colonized the entire waterbody [Matafonov, 2005]. Two years later, G. fasciatus was discovered in the Kuibyshev reservoir, about 400 kilometers downstream from the place of introduction into the Gorkovskoe reservoir and then it was recorded in the Rybinsk, Cheboksary and the Sheksna reservoirs [Matafonov, 2005]. In other regions of introduction, for example in the Onega and Ladoga lakes, G. fasciatus presently occupies all littoral biotopes. Available information includes mainly quantitative characteristics of populations in the Lake Ladoga, as well as observations on its position in benthic communities [i.e., Panov, 1994, 1996; Kurashov et al., 2008, 2012]. Successful establishment of G. fasciatus is due to high ecological plasticity of this amphipod species. In the littoral of the Petrozavodsk Bay of Onega Lake $G$. fasciatus has one-year life cycle with two generations, the overwintering and the summer ones. After introduction in the Lake Ladoga in the first half of the 1980s [Panov, 1994] G. fasciatus became a dominant benthic species in all types of intertidal habitats [Kurashov et al., 2008; Panov, Berezina, 2002]. This led to a significant change in the structure of benthic communities of littoral zone, and at the present time, the invader plays an important role in formation and functioning of the benthic biocenoses in the coastal zone of the lake [Kurashov et al., 2008, 2012].

In the Volga Basin there was a continuing expansion of $G$. fasciatus: the species was recorded near Tver in 2008 [Schletterer, Kuzovlev, 2012] while in 2011 it was found in the lower stream of the River Oka [Puhnarevich, 2013]. However, until now no information was published in the reviewed literature regarding the occurrence of G. fasciatus in the River Moskva, the left tributary of Oka, nor information was presented on its abundance in the areas with different level of antropogenic pollution in central Russia. The aim of the present paper is to report on the occurrence and abundance of this alien species in the Moskva River, known for its long-time and intensive pollution load within the City of Moscow (MosEcoMonitoring, http://www. mosecom.ru/water/fact/).

\section{Material and methods}

In the course of studies on the biological diversity of the River Moskva basin several sites were sampled in April-May 2016; in each site macrobenthic organisms were collected from the area 1 to $1 \mathrm{~m}$ using a hand net. Samples were washed with pure water and fixed with the $70 \%$ ethanol solution. In a total 8 such sites were investigated in three sections of the river: upstream of the Moscow City, inside the borders of the city and downstream of the city (Table 1). One area (site 1), as a "control" site was selected in the area of the Prioksko-Terrasny Nature Reserve (PTNR) in the
Table 1. Sites sampled in the River Moskva in April and May 2016.

Таблица 1. Места сбора материала в р. Москва в апреле и мае 2016 г.

\begin{tabular}{|c|c|c|}
\hline $\begin{array}{c}\text { Site } 1 \\
(\mathrm{PTNR})\end{array}$ & $\begin{array}{c}54^{\circ} 50^{\prime} 40^{\prime \prime} \mathrm{N} \\
37^{\circ} 42^{\prime} 24^{\prime \prime} \mathrm{E}\end{array}$ & $\begin{array}{c}\text { sand, sandy-rocky } \\
\text { substrates, numerous algae }\end{array}$ \\
\hline Site 2 & $\begin{array}{c}55^{\circ} 32^{\prime} 41^{\prime \prime} \mathrm{N} \\
38^{\circ} 6^{\prime} 41^{\prime \prime} \mathrm{E}\end{array}$ & sandy-rocky substrates \\
\hline Site 3 & $\begin{array}{c}55^{\circ} 36^{\prime} 7^{\prime \prime} \mathrm{N} \\
37^{\circ} 51^{\prime} 15^{\prime \prime} \mathrm{E}\end{array}$ & sandy-rocky substrates \\
\hline Site 4 & $\begin{array}{c}55^{\circ} 38^{\prime} 32^{\prime \prime} \mathrm{N} \\
37^{\circ} 46^{\prime} 54^{\prime \prime} \mathrm{E}\end{array}$ & muddy bottom \\
\hline Site 5 & $\begin{array}{c}55^{\circ} 40^{\prime} 18^{\prime \prime} \mathrm{N} \\
37^{\circ} 40^{\prime} 59^{\prime \prime} \mathrm{E}\end{array}$ & muddy bottom \\
\hline Site 6 & $\begin{array}{c}55^{\circ} 45^{\prime} 14^{\prime \prime} \mathrm{N} \\
37^{\circ} 27^{\prime} 6^{\prime \prime} \mathrm{E}\end{array}$ & muddy sand \\
\hline Site 7 & $\begin{array}{c}55^{\circ} 47^{\prime} 34^{\prime \prime} \mathrm{N} \\
37^{\circ} 25^{\prime} 6^{\prime \prime} \mathrm{E}\end{array}$ & sand, rocks \\
\hline Site 8 & $\begin{array}{c}55^{\circ} 46^{\prime} 8^{\prime \prime} \mathrm{N} \\
37^{\circ} 19^{\prime} 4^{\prime \prime} \mathrm{E}\end{array}$ & sand, rocks \\
\hline Site 9 & $\begin{array}{c}55^{\circ} 44^{\prime} 17^{\prime \prime} \mathrm{N} \\
37^{\circ} 12^{\prime} 4^{\prime \prime} \mathrm{E}\end{array}$ & sandy-rocky substrates \\
\hline
\end{tabular}

River Oka. All sites were located in the coastal zone, from the water's edge to the depth of $2 \mathrm{~m}$. Geographic coordinates of sites were determined using Global Positioning Systems (GPS). The substrate in most sites consisted of sand and boulders, and rarely of silty substrates (within the borders of the Moscow City). After collection, all animals were identified and weighed according to standard methods. Samples were examined using a stereoscopic microscope MBS-10 in a Bogorov's chamber. Before weighing using a torsion scale the specimens were dried on filter paper. For several species the stomach and gut contents were dissected to study their nutrition. Average indices of abundance were recalculated for $1 \mathrm{~m}^{2}$.

\section{Results and discussion}

The most common species of crustaceans in the macrobenthos of the River Moskva was the invasive Baikal amphipod Gmelinoides fasciatus. The native gammarid species Gammarus cf. lacustris G.O. Sars, 1864 (Gammaridae) was second in abundance. No other invasive amphipod species, such as the Ponto-Caspian species Pontogammarus robustoides (Sars, 1894) (Pontogammaridae) and Chelicorophium curvispinum (G.O. Sars, 1895) (Corophiidae), observed in the basin of the river Neva and the Gulf of Finland [Malyavin et al., 2008; Kurashov et al., 2008, 2010], were found. Other large crustaceans, such as astacid crayfish Astacus astacus Linnaeus, 1758 (Decapoda: Astacidea: Astacidae) were also absent in the samples. Amphipods reached to more than $70 \%$ of biomass in all samples; other taxa were represented by chironomids, isopods, oligochaetes, aquatic larvae of insects. In the "control" site (site 1) in PTNR abundant coverage of filamentous 
algae was observed while algae were nearly absent within the borders of the Moscow City.

The most numerous aggregations of $G$. fasciatus (580 ind. $/ \mathrm{m}^{2}$ ) were found on sandy-rocky substrates of "control" site in Oka River (PTNR, site 1). In the River Moskva upstream of the Moscow City the abundance ranged from 260 to 380 ind. $/ \mathrm{m}^{2}$ (site 2). Near the city population of this species decreased two times comprising 100-150 ind. $/ \mathrm{m}^{2}$ (sites 3, 6, 7); the species was absent in two silty sites (sites 4 and 5). Downstream of the city, the population density of $G$. fasciatus again increased up to 230 ind. $/ \mathrm{m}^{2}$ (sites 8,9 ) Maximum abundance of the species was confined of the river flow, with a particular increase under stones and other shelters. The population of $G$. fasciatus can be characterized as stable at all studied localities, however, in all studied sites of the River Moskva (sites 2-9) the abundance never reached the "control" values in the River Oka (site 1). The ratio of males and females was close to $1: 1$; the maximum size (body length) of mature males measured $10.5 \mathrm{~mm}$, those of female was $9 \mathrm{~mm}$, with the maximum weight of males and females of 24 $\mathrm{mg}$ and $12 \mathrm{mg}$ respectively.

The population of the native species $G$. lacustris was slightly less abundant on sandy-rocky substrates of the "control" site in the Oka River (site 1). It amounted to about 130 ind. $/ \mathrm{m}^{2}$; upstream of the borders of Moscow City the abundance was lower, i.e. 80 ind. $/ \mathrm{m}^{2}$ (sites 2,3$)$; in the city area it was minimum, 20-25 ind. $/ \mathrm{m}^{2}$ (sites $4-7$ ), including silted station. Downstream of the city it raised up to 85 ind. $/ \mathrm{m}^{2}$ ( sites 8,9$)$. Competition for substratum with the invasive $G$. fasciatus is possible, as both species were found in the investigated areas of the river together. The sex ratio of about 1:1 was similar in both species. In shallow areas $(0-1 \mathrm{~m})$ of the River Moskva mostly juveniles of both species were found while mature individuals and large number of different age groups of animals occurred at intermediate depths (deeper than 1 meter) of the river. The gut content of both species was dominated by fragments of filamentous algae, copepods and rotifers apparently collected from the bottom. This kind of food indicates both species to be generalistic gatherers (scavengers).

Noteworthy, the greatest decrease in abundance of G. fasciatus is observed in the central part of the city, where the most noticeable discharge of polluted waters is recorded (see quarterly data on the pollution level at MosEcoMonitoring website, http://www.mosecom.ru/ water/fact/). However, no significant reduction in the abundance of $G$. lacustris in the same area was found. Comparison of the species abundance at the sites indicates the presence of limiting factors within the border of Moscow City for populations of G. fasciatus. A similar effect of antropogenic pollution on the population of $G$. fasciatus was already observed earlier in the littoral zone of Onega Lake, near Petrozavodsk City [Sidorova, 2013; Sidorova et al, 2012]. This suggests that the introduced species is more sensitive to envi- ronmental conditions and especially anthropogenic pollution than the native amphipod species $G$. lacustris. Consequently, G. fasciatus can be considered as an indicator species of the water quality.

ACKNOWLEDGEMENTS. This work was supported by Russian Foundation of Basic Research (grant \# 15-34-70053 mol_a_mos "The study of the status of populations of freshwater crustaceans in the basin of rivers Moskva and Yauza as one of the factors of monitoring the state of the environment").

\section{References}

Bazikalova A.Ya. 1945. [Amphipods of the Lake Baikal] // Trudy Baikalskoy Limnologicheskoy stantsii. Vol.11. P.3-440 [in Russian].

Beckman M.Yu. 1962. [Ecology and productivity of Micruropus possolkii Sow. and Gmelinoides fasciatus Stebb.] // Sistematika i ekologiya rakoobraznykh Baikala. Trudy Limnologicheskogo Instituta [Systematics and ecology of crustacean of the Baikal Lake. Proceedings of Limnological Institute]. Vol.2. Part.1. P.141-155 [in Russian].

Beckman M.Yu., Bazikalova A.Ya. 1951. [Biology and production possibilitites of some Baikal and Siberian amphipods] // Trudy problemnykh i tematicheskih soveshchanii ZIN [Reports of problematic and tematic meetings of ZIN]. Leningrad. Vol.1. P.61-67 [in Russian].

Greze V.N. 1957. Fodder resources of fishes of the Yenisei and their usage // Izvestiya VNIORKh. Vol.41. P.1236 [in Russian].

Guryanova E.F. 1929. [Notes on fauna of Crustacea-Malacostraca from the Yenisei River] // Russkyi Gidrobiologicheskiy Zhurnal. Vol.8. No.1012. P.285-299 [in Russian].

Guryanova E.F. 1951. [Bokoplavy morei SSSR (Amphipods of the seas of USSR)]. Moscow-Leningrad: Publishing House of Academy of Sciences of USSR. 1029 pp.

Ioffe Tz.I., Nilova O.I. 1975. [Experiments on the acclimatization of Baikal gammarids in the lakes of North-West part of the USSR] // Sbornik nauchnyh trudov GosNIORH [Proceedings of GosNIORKH]. Vol.103. P.249-254 [in Russian].

Kamaltynov R.M. 2001. [Amphipods (Amphipoda: Gammaroidea)] // Annotirovanyi spisok fauny ozera Baikal i ego vodosbornogo basseina [An annotated list of fauna of the Lake Baikal and its drainage basin]. Vol.1. Part.3. Novosibirsk: Nauka. P.572-831 [in Russian].

Kozhov M.M. 1947. [Fauna of the Lake Baikal]. Irkutsk. 303 pp. [in Russian].

Kurashov E.A., Barkov D.V., Rusanov A.G., Barbashov M.A. 2008. [The role of Baikal invader Gmelinoides fasciatus (Stebbing, 1899) in the formation of cross-border flow of matter and energy in the littoral zone of the Ladoga Lake] // Problemy izucheniya kraevykh struktur biotsenozov: Materialy II-oi nauchnoy konferentsii s mezdunarodnym uchastiem [Problems of investigations of border structures of biocenoses: Proceedings of the IInd scientific conference with international participation. Saratov]. Saratov: Saratov University Press. P.54-58 [in Russian].

Kurashov E.A., Barbashov M.A., Panov V.E. 2010. First finding of Ponto-Caspian invasive amphipod Chelicorophium curvispinum (G.O. Sars, 1895) (Amphipoda, Crustacea) in Lake Ladoga // Russian Journal of Biological Invasions. Vol.1. No.4. P.282287.

Kurashov E.A., Barbashov M.A., Barkov D.V., Rusanov A.G., Lavrov M.S. 2012. [Invasive amphipods as a factor of transformation of Lake Ladoga ecosystems // Russian Journal of Biologiccal Invasions. Vol.3. No.3. P.202-212.

Malyavin S.A., Berezina N.A., Hwang J.-Sh. 2008. [On the first record of Chelicorophium curvispinum (Amphipoda, Crusta- 
cea) in the Finland Bay of the Baltic Sea] // Zoologicheskiy Zhurnal. Vol.87. No.6. P.643-649 [in Russian].

Matafanov D.V. 2003. [Comparative ecology of amphipods: Gmelinoides fasciatus (Stebbing, 1899) and Gammarus lacustris (Sars, 1863) in Ivano-Arahley lakes]. PhD thesis. Ulan-Ude. 2003. 20 p. [in Russian].

Matafanov D.V. 2005. [Baikal endemic Gmelinoides fasciatus (Micruropodidae, Gammaroidea, Amphipoda) in the Arahley lake] // Zoologichesky Zhurnal. Vol.84. No.3. P.321-325 [in Russian].

Mitskevich O.I. 1978. [The intensity of metabolism of Gmelinoides fasciatus Stebb. acclimatized in the Otradnoe lake of the Leningrad region] // Sbornik nauchnykh trudov GosNIORH. Vol.24. P.42-47 [in Russian].

Mitskevich O.I. 1981. [The productivity of Gmelinoides fasciatus Stebb. acclimatized in the Otradnoe lake (the Leningrad region)] // Sbornik nauchnykh trudov GosNIORH. Vol.25. P.3038 [in Russian].

Mitskevich O.I. 1981. [The consumption of acclimatized gammarids by the fishes in the Otradnoe lake] // Sbornik nauchnykh trudov GosNIORH. Vol.173. P.71-76 [in Russian].

Mitskevich O.I. 1984. [An estimation of results of acclimatizaion of Baikal amphipod Gmelinoides fasciatus Stebb. in water reserves of the European part of USSR] // Sbornik nauchnykh trudov GosNIORH. Vol.223. P.73-78 [in Russian].

Mitskevich O.I. 1988. [Ecological effectivity of acclimatization of fodder amphipod Gmelinoides fasciatus (with an example of Otradnoe lake in the Leningrad region)] // Sbornik nauchnykh trudov GosNIORH. Vol.283. P.89-98 [in Russian].

MosEcoMonitoring [Results of observations on contaminants level]. The Government of Moscow. Department of Natural Resources and Environmental Protection. http://www.mosecom.ru/ water/fact/. Last access in August 2016 [in Russian].
Panov V.E. 1994. [Baikal endemic amphipod Gmelinoides fasciatus Stebb. in the Ladoga Lake] // Doklady Akademii Nauk. Vol.336. No.2. P.279-282 [in Russian].

Panov V.E., Berezina N.A. 2002. Invasion history, biology and impacts of the Baikalian amphipod Gmelinoides fasciatus (Stebbing) // Leppakoski E. et al. (eds.) Invasive Aquatic species in Europe. Dortrecht: Kluwer Publishers. P. 96-103.

Pirozhnikov P.L. 1937. [Marine and Baikal elements in the fauna of the Yenissey River] // Bulleten Moskovskogo obshestva ispytateley prirody. Otdelenie biologii Vol.46. No.3. P.165172 [in Russian].

Pirozhnikov P.L. 1955. [On the entrichment of feeding base of lakes and water reserves] // Zoologicheskiy Zhurnal. Vol.34. No.2. P.267-278 [in Russian].

Pukhnarevich D.A. 2013. [Zoobenthos of the lower stream of Oka river] // Vestnik Nizhegorodskogo universiteta im. N.I. Lobachevskogo [Reports of N.I. Lobachevskogo Nizhegorodskyi University]. Vol.11. No.1. P.128-135 [in Russian].

Schletterer M., Kuzovlev V.V. 2012. Documentation of the presence of Gmelinoides fasciatus (Stebbing, 1899) and the native benthic fauna in the Volga River at Tver (Tver Region, Russia) // Aquatic Insects. Vol.34. Sup1. P.139-155.

Sidorova A.I. 2013. [The method of using of macrozoobenthos parametres for the estimation of ecological quality of urbant territory (with an example of Petrozavodsk City)] // Uchenye zapiski Rossiiskogo gosudarstvennogo gidrometeorologicheskogo universiteta [Scientific reports of Russian State Hydrometerological University]. Vol.28. P.104-109 [in Russian].

Sidorova A.I., Kalinkina N.M., Dydik I.V. 2012. [Reaction of Baikal amphipod Gmelinoides fasciatus Stebbing on the influence of urbant storm drains from Petrozavodsk city] // Trudy Karelskogo nauchnogo tsentra RAN [Reports of Karelian scientific center of RAS]. Vol.2. P.125-130 [in Russian].

Responsible editor V.A. Spiridonov 